\title{
thnicities
}

Copyright $\odot$ SAGE Publications 2008 (Los Angeles, London, New Delhi, Signapore and Washington DC) 1468-7968 Vol 8(4): 536-576; 088925

DOI: $10.1177 / 1468796808088925$

http://etn.sagepub.com

\section{Everyday nationhood}

\section{JON E. FOX}

University of Bristol, UK

\section{CYNTHIA MILLER-IDRISS}

New York University, USA

\section{INTRODUCTION}

Contrary to the predictions of some, neither the proliferation of supranational forms of governance, the ascendancy of free market principles of global capitalism, nor expanding flows of transnational migration have unseated the nation state as the dominant form of political organization in the world today. From violent secessionist movements in the former Yugoslavia and Soviet Union to a growing backlash against immigration and multiculturalism in Europe and North America, nationalism and its xenophobic correlates continue to flourish in - and adapt to - a changing world.

Nationalism is the project to make the political unit, the state (or polity) congruent with the cultural unit, the nation. Attempts to accomplish this congruence have been studied from a variety of macro-analytical perspectives. Nationalism has been examined as a political ideology holding that each state should have its nation and each nation its state; as the historically contingent outcome of modernizing and industrializing economic forces that bring the state into alignment with the nation; as a cultural construct of collective belonging realized and legitimated through institutional and discursive practices; and as a site for material and symbolic struggles over the definition of national inclusion and exclusion.

The targets of these endeavours are the people themselves: to make the nation is to make people national. Through the promotion of standardized languages, national (and nationalist) educational curricula, military conscription and taxation - and the more nefarious methods of war, forced 
assimilation, expulsion and extermination - the nation, or people, are made one with their state. Nationalism recasts the mosaic of diverse peoples within the boundaries of the state (or polity) into a uniform and unified national whole; it turns, as Eugen Weber (1976) put it, 'peasants into Frenchmen'. Yet while there is consensus that nationalism is a mass phenomenon, the masses have been curiously missing from much of the scholarship (Whitmeyer, 2002). The focus on the political, economic and cultural determinants of popular nationalism has not systematically accounted for the popularity of nationalism. Rather, the people in whose names nations are being made are simply assumed to be attuned to the national content of their self-appointed nationalist messengers. Nationhood from this perspective resonates evenly and unwaveringly among the people; the nation is a fait accompli.

The nation, however, is not simply the product of macro-structural forces; it is simultaneously the practical accomplishment of ordinary people engaging in routine activities. Eric Hobsbawm (1991: 10) acknowledges that while nationalism is ' . . constructed essentially from above, [it] . . cannot be understood unless also analyzed from below, that is in terms of the assumptions, hopes, needs, longings and interests of ordinary people, which are not necessarily national and still less nationalist'. Recently there has been increased interest in the ways in which nationhood is negotiated and reproduced - and sometimes undermined and subverted (Herzfeld, 1997) in everyday life (Billig, 1995; Edensor, 2002, 2006). These approaches do not dispute the popular resonance of nationhood; to the contrary, they describe the ways in which nations (and people's attachments to them) have become a taken-for-granted part of the landscape of things (Billig, 1995: 38; Edensor, 2002: 88).

But the general ways in which nationhood can resonate do not account for the specific ways in which nationhood actually does resonate - to the extent it does so at all (Thompson, 2001: 28). Rather than deducing the quotidian meaning and salience of nationalism from its political and cultural privileging, our aim in this article is to develop a research agenda for examining the actual practices through which ordinary people engage and enact (and ignore and deflect) nationhood and nationalism in the varied contexts of their everyday lives. ${ }^{1}$ Following Hobsbawm, we examine nationalism 'from below'.

Our examination considers four ways in which nationhood is produced and reproduced in everyday life. ${ }^{2}$ First, we explore the ways in which the nation as a discursive construct is constituted and legitimated not (only) in response to elite dictates but also according to the contingencies of everyday life. This is 'talking the nation': the discursive construction of the nation through routine talk in interaction. Second, we turn to the ways in which nationhood frames the choices people make. This is 'choosing the nation': nationhood as it is implicated in the decisions ordinary people 
make. Third, we explore the everyday meanings and invocations of national symbols. This is 'performing the nation': the production of national sensibilities through the ritual enactment of symbols. Fourth, we examine national distinction in the mundane tastes and preferences of ordinary people. This is 'consuming the nation': the constitution and expression of national difference through everyday consumption habits.

Our survey of these four modalities of everyday nationalism sheds light on some of the ways in which ordinary people are active participants in the quotidian production and reproduction of the nation. But while these approaches give us a better idea of what everyday nationalism is, they don't provide consensus on how everyday nationalism should be studied. In the final portion of the article, we draw on these diverse traditions to elaborate our own methodological agenda for the empirically grounded investigation of the nation in everyday life. Our aim is to operationalize a research strategy for uncovering both the micro-processes and macro-dynamics of nationhood as it is invoked and evoked by its everyday practitioners.

\section{TALKING THE NATION}

How, then, does the nation become a meaningful idiom in everyday life? For one, people talk about it. They make discursive claims for, about and in the name of the nation. As Craig Calhoun (1997: 5) points out, 'nations are constituted largely by [these] claims themselves, by the way of talking and thinking and acting that relies on these sorts of claims to produce collective identity, to mobilize people for collective projects, and to evaluate peoples and practices'. The nation, in this view, is a discursive construct. Discourse analytical approaches to the study of nationalism emphasize the ways in which understandings of nationhood are engaged, constituted and propagated through discursive acts (Dijk, 1984; Wetherell and Potter, 1992; Wodak et al.,1999). These discursive acts are not simply descriptive of social reality; they are simultaneously constitutive of that reality, willing into existence that which they name (Bourdieu, 1991: 223).

Much of the scholarship has focused on the important role elites play in articulating and propagating visions of the nation that have the potential to both resonate with and shape popular perceptions of the nation (Suny and Kennedy, 2001; Verdery, 1991). But the actual degree to which these elite depictions are appropriated by ordinary people (to the extent they are so at all) has received less scholarly attention. Parallel to this, there has been increasing interest in the ways the nation is discursively invoked and constituted by ordinary people. This talk does not simply follow the stylized contours of elite discourse; rather, it responds to the logics, imperatives and concerns of the everyday contexts in which it is embedded. This scholarship 
does not take elite discourse as its starting point but examines the ways in which ordinary people talk about and with the nation in ways that matter to them.

\section{Talking about the nation}

Scholars recently have begun asking ordinary people what the nation means to them (Miller-Idriss, 2006; Thompson and Day, 1999; Wodak et al., 1999). Using qualitative interviewing techniques, researchers are beginning to capture ordinary people's previously unrecorded articulations of the nation, national identity and national belonging. Findings reveal that these people's representations of the nation do not simply mimic those variants traded in elite discourse, but more often resonate with the currents and rhythms of their everyday concerns and predicaments. Miller-Idriss's (forthcoming) interviews with young working-class Germans in vocational schools showed how their discursive claims of national pride departed from, and at times explicitly challenged, official sanctions against expressions of German national sentiment. Andrew Thompson and Graham Day (1999) interviewed ordinary people in Wales to reveal the mundane ways in which they gave discursive content to their understandings of Welshness. And in Austria, Ruth Wodak and colleagues (1999) assembled focus groups and conducted in-depth interviews to show how ordinary Austrians constructed national understandings of themselves with reference to immigration issues, Austria's Nazi past, and the European Union.

Michael Billig (1995) has observed how nationhood often operates at the level of unselfconscious disposition (what Edensor (2002: Chapter 3) terms, after Bourdieu, 'national habitus'). Discourse analytical approaches to the study of nationalism, in contrast, draw attention to the ways in which nationhood can also be creatively and self-consciously deployed and manipulated by ordinary people. In this view, nationhood is not (only) lurking in the crevices of the unconscious, furtively informing talk without becoming the subject of talk; it is simultaneously the practical accomplishment of ordinary people giving concrete expression to their understandings of the nation. Nationhood does not only define their talk; it is defined by their talk.

In these ways, ordinary people give discursive shape and content to their otherwise taken-for-granted understandings of the nation. Implicit nationhood is made explicit through interviews and focus groups, shedding light on the processes through which nationhood is discursively constructed. Understandings of the nation cloaked by the fog of commonsense or obscured by the traumas of history are teased out by skilled researchers. These studies reveal the importance of shifting the analytical focus to ordinary people as active producers - and not just passive consumers - of national discourse. 


\section{Talking with the nation}

But this practical capacity to talk nationally does not, in itself, explain how such talk occurs spontaneously (to the extent it does so at all) in the course of people's everyday lives. When called upon, ordinary people can call forth and articulate their more-or-less taken-for-granted assumptions about what the nation means to them. But when are they called upon? Just because people can talk about the nation doesn't mean that they $d o$. While discourse analytical approaches are useful for appreciating the everyday contents of the nation, they have less to say about locating its everyday contexts.

National catastrophes, wars and, not least of all (see later), international sporting events, provide important contexts for everyday articulations of the nation. Ordinary people recognize, interpret and align themselves with pressing issues in explicitly national terms. But most of the time, the nation is not something ordinary people talk about; rather, it's something they talk with. This is the nation not as the object of talk but rather as an unselfconscious disposition about the national order of things that intermittently informs talk. The nation in this sense is a way of seeing, doing, talking and being that posits and sometimes enacts the unproblematic and naturalizing partition of the world into discrete ethnocultural units (Brubaker, 2004). It is not (only) a topic of talk, but also a culturally available schema that can be discursively deployed to make sense of other topics of talk, explain predicaments and order social difference (Gamson, 1992). When national frames are discursively invoked, social actors become national actors, diverse phenomena become national phenomena and everyday stories become national stories.

The nation does not resonate evenly across time or space; it comes to matter in certain ways at particular times for different people. The question thus shifts from 'what is the nation?' to 'when is the nation?'. ${ }^{3}$ When - in what situations - does the category of nation become a salient frame for routine talk and interaction? The answer, it turns out, is not very often. Most of the time nationhood does not frame people's understanding of themselves, their interactions or their predicaments. Take the example of Cornel, a Romanian university student in the Hungarian-minority town of Cluj, Romania. Cornel explained how it was a year before he realized his friend, 'Şoni', was Hungarian. 'He didn't have an accent at all', he explained. 'In the first year I knew him, I didn't know he was Hungarian. I knew his name was "Şoni," and so I said to him, "... Şoni, do you speak Hungarian," "yeah, I speak Hungarian," . . but he had only Romanian friends. . . It was a year before I figured out he was Hungarian.' His brother teased him: 'After a year, he comes out with "maybe he's Hungarian ....'. By speaking unaccented Romanian, socializing in nationally unmarked ways, and not explicitly advertising his Hungarianness, Şoni ['Sanyi' in Hungarian] remained ethnonationally invisible to Cornel. It wasn't that Şoni wasn't 
Hungarian. He was. It was that his Hungarianness hadn't been an experientially salient feature of his interactions with Cornel (Fox, 2004b: 115-61; see Richard Jenkins' (1997: 56) distinction between 'nominal' and 'virtual' identities).

Since nationhood does not define people's experiences of all interactions all the time, the everyday contexts in which it is discursively invoked by ordinary people need to be identified. Brubaker et al.'s (2006) ethnography of Cluj, Romania traced the ways interactions between friends, neighbours, classmates and colleagues momentarily become ethnic or interethnic interactions. Gerd Baumann's (1996) ethnography of immigrants in a workingclass London neighbourhood similarly depicted how local understandings of community took shape according to the logics and rhythms of everyday life. And in Hungary, labour migration provided the context for ethnic Hungarian migrant workers from Romania to articulate and elaborate new forms of belonging that distinguished themselves nationally from their hosts of the same name (Fox, 2007). Studies like these have situated the discursive enactment and construction of nationhood in the routine contexts of everyday life.

But contexts are not only understood as domains of daily activity; they also include the more fleeting micro-interactional and discursive moments that happen intermittently in the course of these activities. Recently, a growing body of research has pointed to the ways in which language and other audible and visual cues trigger an awareness of category membership through everyday interaction. Earlier, Cornel remarked that Şoni 'didn't have an accent at all'. Had he an accent (or had he simply spoken Hungarian in the first place), Şoni may very well have become more transparently Hungarian to Cornel. In contexts where language is taken as a criterion of ethnonationality, linguistic conventions such as accent, intonation and syntax can signal ethnonational membership (Giles, 1979: 255-9; Gumperz, 1982: 32-3). Gábor, another Hungarian studying at the Technical University, reported how his poor Romanian competency marked him as Hungarian to his Romanian classmates. 'They knew, everybody knew I was Hungarian, it was impossible not to know I was Hungarian', he insisted. 'They could figure it out right away from how poorly I spoke Romanian . . . - it was as if I had been black. "He's Hungarian ..." - that was completely obvious to everyone.' While Şoni's/Sanyi's flawless Romanian concealed his Hungarianness, Gábor's accented Romanian revealed his own Hungarianness. ${ }^{4}$

To be sure, most of the time, language communicates information other than nationality. But there are certain contexts when the choice of language being spoken, or the way it is spoken, communicates membership in an ethnonational community. In Catalonia, Kathryn Woolard (1989) has shown how routine shifts between Spanish and Catalan make ethnic affiliations momentarily transparent in everyday interactions. Similarly, Monica 
Heller's research from Quebec (1999) has revealed how spoken French is both deployed and perceived as constitutive of Frenchness. And Katharine Jones (2001) has examined how English people living in the USA develop strategies for self-consciously deploying English accents to preserve and advertise their Englishness to others. These discursive strategies and linguistic conventions make nationhood momentarily salient in everyday talk and interaction. They turn nominally interethnic interactions into experientially interethnic interactions.

This is nationhood as it is meaningfully embodied, expressed and sometimes performed in the routine contexts of everyday life. The nation as a discursive construct is reproduced not only through direct discursive engagement, but also as it is implicated tangentially through talk and interaction. It is the practical accomplishment of ordinary people talking about themselves and their surroundings in ways that implicate and reproduce a national view of the world (Fox, 2004a). These are the micro-settings for the invocation and reproduction of nationhood in everyday life.

\section{CHOOSING THE NATION}

Nationhood is also implicated in the choices people make. People 'choose' the nation when the universe of options is defined in national terms. Reading a nationalist newspaper or sending one's child to a minoritylanguage school can thus be defined and experienced as national choices. Nationhood can also be the contingent outcome of other (non-national) choices. Thus, choosing (or approving) marriage partners or socializing with friends, while not necessarily explicitly national, can structure the trajectories of future choices in ways that reinforce nationhood as a salient idiom of belonging.

\section{Making national choices}

There is a growing body of scholarship on the ways in which institutions and their organizational logics shape experience (Brinton and Nee, 1998; Powell and DiMaggio, 1991). Institutions organized according to national logics legitimate and propagate a national view of the world (Brubaker, 1996). From nationally defined schools in Wales and Quebec to self-government in Catalonia and South Tyrol, educational, media, governmental, cultural, religious and other institutions can be formally or informally arranged according to national logics. These institutions present those who encounter them with a menu of nationally defined options. In Transylvania, for instance, Hungarian minority schools and (de facto) churches operate alongside their Romanian majority counterparts. Decisions about whether 
to send one's child to a Hungarian school or to get married in a Romanian Orthodox church can thus confront mothers and fathers and husbands and wives with opportunities to momentarily (if not durably) become Romanian and Hungarian. National belonging is implicated - and sometimes explicitly reflected upon, hashed over and debated - in the institutionally mediated choices people make (Brubaker et al., 2006: 272-3, 297).

On the one hand, nationally defined institutions can offer their claimants symbolic rewards: the chance to be (or become) national. In some cases, choosing a national minority school for one's child can be viewed as a form of insurance against assimilation. On the other hand, institutions can also offer their claimants material rewards: the incentive to be (or become) national. In many parts of the world, nationality and ethnicity have been institutionally adopted, operationalized and legitimated as the preferred language of claims-making (Koopmans and Statham, 1999; Olzak and Nagel, 1996). Affirmative action programmes in the USA, multiculturalism in Canada and pillarization in the Netherlands have all rechristened and partitioned the social landscape as an ethnocultural landscape. In these contexts, questions of who gets what can be determined (or perceived to be determined) by who is what in ethnonational terms (see, for example, Banton, 1983).

For the ordinary people encountering these institutions, national and ethnic attachments just became worth something. Institutional configurations that offer material rewards according to national or ethnic criteria encourage their claimants to view nationality or ethnicity as a resource that can be strategically deployed (or concealed or manipulated) to secure access to these rewards. Thus, the reconfiguration of political opportunity structures according to ethnoracial criteria in the USA in the 1960s and 1970s encouraged and even (re-)invented 'Native American' as a materially (and ultimately symbolically) viable category of belonging (Nagel, 1996). In the Baltics following the collapse of the Soviet Union, legislation that made language a criterion of citizenship compelled ethnic minority Russians to recalculate the benefits of learning the titular languages of the countries in which they lived (Laitin, 1998). And in Romania, admissions quotas for ethnic minority students at the 'multicultural' Babeş-Bolyai University invited applicants to consider and claim minority status to improve their chances of admission (Fox, 2004b). By literally (or figuratively) ticking boxes, people 'choose' ethnonationality, momentarily invoking it and making it materially salient. Categories of belonging that may have had little symbolic significance can nevertheless become materially consequential when linked to the politics of redistribution.

This does not mean, however, that nationally marked institutions always make nationhood experientially salient. They don't. In many situations, the institutions people encounter are seen less as gateways to material (or symbolic) rewards than as simple sorting mechanisms. Krisztina, a 
Transylvanian Hungarian history student enrolled in a Hungarian line of study at her Romanian university explained that she never considered enrolling in the Romanian line. 'Why would I want to study in Romanian?', she asked, genuinely perplexed. Transylvania 'is a Hungarian region, Hungarian is my native language, I know Hungarian ... better than [Romanian], so?' After having attended exclusively Hungarian minority schools all her life, Krisztina did not choose to continue her studies at the university in Hungarian. Rather, she chose to study history. It was selfevident that such choices would be made within an institutionally prescribed Hungarian universe (Fox, 2004b: 87-8; see also Brubaker et al., 2006: 272-73).

Choosing a minority school can thus be like choosing a toilet - the signs on the doors tell people where to go. In this sense, 'choosing' is hardly a 'choice': it's unreflective, automatic. Nationhood operates as an unselfconscious disposition: it underwrites people's choices without becoming a selfconscious determinant of those choices (Bourdieu, 1977: 166; Bourdieu and Passeron, 1977: 54-67; see also Foucault's (1995[1977]: 177-84) notion of 'normalization'). To conceal nationhood in this way, however, is not to enfeeble it. Rather, institutions powerfully reinforce their national logics by reproducing nationhood as a taken-for-granted fixture of the social world (Billig, 1995: 37-42). Nationhood defines the parameters, but not the content, of people's choices.

\section{Making choices national}

Institutions do not only structure choices at the point of entry; they also mediate subsequent choices that occur inside - and outside - of their confines. Friendship and partner choices can be deeply structured according to the logics of the institutions in which people are embedded. Nationally delineated institutions thus make nationhood a powerful but mostly invisible parameter of social relations by offering a template for the formation and reproduction of social relations according to their national logics (Brubaker et al., 2006: 273-5). They shape social relations by proscribing the limits and rules of interaction (Bourdieu and Passeron, 1977; see also Bourdieu, 1977: 164-7; Foucault, 1995[1977]: 177-84).

In nationally circumscribed universes, then, choices are usually made according to non-national criteria. Emese, a classmate of Krisztina introduced above, did not choose to socialize at the university with other Hungarians because they were Hungarian. She chose them because they were there. Friendship choices were ordered according to other criteria: 'boys and girls in the first place', she explained, 'then ... shared interests, like there's this girl I'm good friends with because we like the same kinds of films, we go to the same lectures, we have lots of things in common'. In nationally defined institutions, people don't have to choose friends on the 
basis of national affinity because the institutions, in effect, do it for them (Fox, 2004b: 113-16). Nationhood does not experientially frame friendship choices; rather it is the contingent outcome of unselfconscious choices mediated by nationally defined institutions (see, e.g. Tilly, 1998: 79-83).

People's choices can thus become important occasions for the enactment and reproduction of national sensibilities. When ordinary people encounter institutions displaying national menus of options, nationhood can become an experientially salient frame for the choices they make. When these same people are already embedded in nationally circumscribed institutions, nationhood silently structures the logic of subsequent choices they make. This is nationhood not only as the practical accomplishment of people's national ponderings, but also as the contingent (yet durable) outcome of other institutionally mediated choices. Nationhood shapes, and is shaped by, people's choices.

\section{PERFORMING THE NATION}

Nationhood is also given symbolic meaning in the ritual performances of everyday (and not-so-everyday) life. Symbols are the cultural ciphers through which meanings are assigned to phenomena and attachments made between people and things (Geertz, 1973: 216). National symbols - flags, anthems, statues and landmarks - are neatly packaged distillations of the nation: they are the linchpins that connect people to the nation (Cerulo, 1995; Smith, 1986). Rituals provide occasions for the visual and audible realization of these symbolic attachments. Through the choreographed exhibition and collective performance of national symbols, those in attendance are united in the transitory awareness of heightened national cohesion. The electricity of the crowd, momentarily subsuming the individual to the collective, generates the experience of 'collective effervescence' (Durkheim, 1995[1912]: 217-18; see also Turner's (1969: 132-6, 153) notion of 'spontaneous communitas'). While such experiences of exultation are necessarily infrequent and ephemeral, their impact on the national sensibilities of the ordinary people who engage in them can be more durable.

This is everyday life characterized not by its banality, but rather by the ordinary individuals who people it. Indeed, these events do not belong to the realm of the ordinary; rather, by definition, they are extraordinary events. They occur infrequently, punctuating the monotony of life at regular, fixed intervals as contrived occasions for the crystallization of national awareness (Mosse, 1975). Public spaces adorned with the symbolic accoutrements of the nation - flags, banners, songs and speeches - provide explicitly national parameters to facilitate the organization and experience of national solidarities (on the integrative function of symbols and rituals, see 
Turner, 1967, pp. 22, 48-50). Songs sung, chants chanted, banners unfurled and flags waved, all in unison, make the bonds that join one another momentarily visible and audible (Cerulo, 1995). 'By expressing the social unity tangibly', Durkheim (1995[1912]: 231-2) explains:

it makes the unit itself more tangible to all ... [F]or the emblem is not only a convenient method of clarifying the awareness the society has of itself: It serves to create - and is a constitutive element of - that awareness ... It is by shouting the same cry, saying the same words, performing the same action in regard to the same object that they arrive at and experience agreement.

National bonds don't simply become transparent through their ritual performance; they are constituted through the collective act of performance.

Whether through the sacred liturgical observances staged by the Nazis at Nuremberg (Mosse, 1975), the elaborately orchestrated dramas performed by Italian Fascists in Rome (Berezin, 1997), the festive pageantry of Soviet baton twirlers and nuclear missiles parading through Red Square (Petrone, 2000), or simply the ritual fireworks and backyard barbecues celebrating the Fourth of July in the USA (Spillman, 1997), national holiday commemorations are key sites for the affirmation and reaffirmation of national bonds.

\section{Mixed messages}

But the explicitly national designs of these public performances do not, in themselves, ensure the generation of explicitly national solidarities. Most of the scholarship on national symbols and the rituals that deliver them has focused on their elite production. Yet the actual ways in which the meanings of these symbols are consumed - perceived, interpreted, negotiated and constituted - by those in attendance does not unambiguously follow from their elite designs. The national messages conveyed by symbols are mixed - if not missed altogether (Kolst $\varnothing, 2006$ ). They are mixed because symbols are inherently multivocal and multivalent: they mean different things to different people at different times. While the state or polity may have the upper hand in affixing national meanings to symbols, both their meanings and valences remain subject to negotiation and reinterpretation by their receiving audiences. People are not just consumers of national meanings; they are simultaneously their contingent producers.

The meanings and uses ordinary people make of national holiday commemorations cannot be simply deduced from the intentions of their architects (Kligman, 1983). To what extent do Fourth of July celebrations in the USA engender the sort of 'collective effervescence' described by Durkheim? Are the principles of liberté, égalité and fraternité experienced - and constituted - by the ordinary French citizens attending Bastille Day commemorations? The nationalist passions of the multitudes are not always 
ignited by national holiday commemorations. Rather, such events often become occasions for family outings or consumer spending rather than the public affirmation of national pride. The national symbols adorning these commemorations are viewed by many as commercialized accessories, denuded of their officially sanctioned national venerability. In other parts of the world, official commemorations become sites for protest and struggle. Flag-waving is replaced by flag-burning as the cherished symbols of the nation are inverted and subverted by would-be revolutionaries. These unintended uses of national symbols undermine their ability to generate the unambiguous experience of national allegiances (Fox, 2006: 221-22).

This is not to suggest that national solidarities are no longer publicly performed. The venue, however, has changed. While collective attachments are not typically generated on the stage of national commemorations, they are on the pitch of international sporting competitions. Indeed, in many countries, it's sports - not holidays - that capture the (national) imagination and inspire the (national) passions of the masses. Shifting the analytical focus from the producers of national symbols to their everyday consumers entails a concomitant search for the sites where those symbols are wielded and manipulated by ordinary people.

The international profiles of World Cup football, the Olympics and other international sporting competitions provide explicitly national parameters for the organization and experience of collective belonging. Fans display their loyalties to their team by borrowing the symbolic repertoire of their respective nations - the flags, the anthems, the colours and even the myths. Ordinary people who might otherwise show little interest in their national attachments are nonetheless capable of displaying their allegiances at sporting competitions with passion. The dramatic unfurling of national flags and poignant singing of national anthems at the medal ceremonies of the Olympics can bring tears to the eyes of adulating fans. 'God Bless America', sung during the seventh inning stretch of baseball games, generated similar responses among some of the post-9/11 crowds. And the exuberance of fans saluting their teams at World Cup matches is unrivalled. Indeed, in these and other cases, fans momentarily become the physical embodiment of the nation. Singing the same songs, chanting the same chants and responding to the rhythms of the competitions in unison - with their faces painted, flags draped over their shoulders, and their t-shirts, scarves and jackets emblazoned in the national colours - these fans physically encapsulate and communicate national allegiances.

Sports are able to succeed where holidays fail due in part to the drama inherent in competition (Elias and Dunning, 1986: 40-8). This drama keeps those in attendance fixated on the action as it unfolds, providing them with a common focus (conveniently dressed in national colours) for their collective engagement. As Eric Hobsbawm (1991: 143) observed: 'The imagined community of millions seems more real as a team of eleven named people'; 
the football team exemplifies and concretizes the nation (see also Eriksen, 1993: 10-11). And through television, the boundaries of this imagined community extend far beyond the confines of sporting stadiums. Transfixed to their screens in bars and living rooms around the world, fans everywhere experience excitement, tension, hope and dejection at precisely the same moments. These shared experiences unite them in a spatially dispersed community virtually connected through television and temporally bounded by the duration of the competition (Moores, 1993: 86-8). This is the nationalism that attracts the masses.

\section{Missed messages}

But neither sporting competitions nor holiday commemorations can claim the loyalties of those who simply don't show up or tune in to them. National holiday commemorations tend to inspire more scholarly investigation than popular participation; and sports produce and reproduce a heavily masculine version of the nation. The meanings of national symbols on parade at these events are simply missed by large segments of their potential audiences. No matter how carefully orchestrated or creatively manipulated, national holidays and sporting events can only engender solidarities for those who are physically or virtually present.

Even the most impressive symbols ensconced in statues, monuments and landmarks vary in their ability to attract attention (Brubaker et al., 2006: 145-6). When new, such symbols might capture the public imagination, instilling people with a sense of national pride. After 9/11, there was an explosion of flags (and patriotic fervour) across the USA. Flags (already a prevalent feature of the American national landscape) proliferated like never before, hanging from front porches, affixed to car windows, pasted on billboards and stitched into clothing. For a time, it was impossible not to notice this explosion of red, white and blue. But only for a time. As time passed, the extraordinary became assimilated into the ordinary, and the American consciousness absorbed these changes as a part of a new standard in flag bearing. Their colours faded and their fringes frayed, symbols that once inspired national attachments become camouflaged against the backdrop of the familiar. Over time, the flags became an unremarkable fixture of the environment, neither requiring (nor receiving) much attention. Once impossible to ignore, the flags now became impossible to notice.

Symbols like these miss their mark. Unseen, unheard and unnoticed, symbols do not and cannot generate national attachments. But this does not in itself render them ineffective. Indeed, there are relatively few moments when flags are exuberantly waved, monuments solemnly venerated and national anthems proudly sung. Most of the time, symbols draw their power in other more invisible (if not invidious) ways. Flags hanging limply from buildings and monuments as inconspicuous as trees or lampposts are 
effective not because they attract attention but because they don't attract attention. These symbols stealthily concoct and legitimate a world of nations without inviting critical engagement. '[N]ational identity in established nations is remembered', Michael Billig (1995: 38) explains:

because it is embedded in routines of life, which constantly remind, or 'flag', nationhood ... [T] hese reminders, or 'flaggings', are so numerous and they are such a familiar part of the social environment, that they operate mindlessly, rather than mindfully. The remembering, not being experienced as remembering, is, in effect, forgotten.

Flags thus don't have to be saluted or waved to work their national magic. The near complete assimilation of nationhood into the realm of the ordinary - not its sporadic or spectacular invocations - testifies to its prosaic power.

Some rituals also belong to this realm of the ordinary. Flag ceremonies or school prayers, for instance, are occasions not for the heightened experience of national belonging but for the veiled reproduction of national sensibilities (Kolst $\varnothing, 2006$ : 677-8). The pledge of allegiance that starts the school day in classrooms across the USA relies neither on fireworks nor flamboyance but rather on the unthinking and unquestioned performance of the nation (Rippberger and Staudt, 2003). The daily repetition of this ritualized national text does not - and indeed cannot - inspire the experience of collective effervescence. Rather, its dull, rote repetition, performed mindlessly and dispassionately, is a national genuflection, instilling in the pupils taken-for-granted loyalties to the abstract notion of the nation. Its effectiveness is measured not in moments but in lifetimes.

There are many ways in which national symbols intersect with the lives of ordinary people, from the extraordinary to the ordinary, from the obvious to the oblivious, from the profound to the prosaic. Much of the scholarship on national symbols and their ritual platforms, however, has focused either on their formal properties or elite production. To understand symbols' popular meaning and resonance, the lens needs to be refocused on the ordinary people who engage and interpret - and ignore and deflect - them (Fox, 2006; Zubrzycki, 2006).

\section{CONSUMING THE NATION}

Nations are not natural or enduring givens, but politically contested and historically contingent social constructs. They are the products (and in some cases unintended consequences) of various standardizing, universalizing, bureaucratizing and culturally indoctrinating processes more or less coordinated by states and their agents. National holidays, as we have just seen, are 
produced and performed to induce and reproduce national solidarities. Museums present a more static display of the nation, assembling people, places and events of the nation into a coherent national narrative to be viewed, learned, remembered and venerated (Anderson, 1991; Zubrzycki, 2006). State-run media also play a key role in the production of national ideologies and the dissemination of national ideas (Moores, 1997). And schools are perhaps the most important sites for developing and transmitting the content and contours of the nation (Bourdieu and Passeron, 1977; Weber, 1976). Their officially sanctioned curricula, conveniently packaged in textbooks, displayed in national emblems and performed in ritual practices, inculcate the students with the values, myths and norms of the nation (Hahn, 1998; Soysal and Schissler, 2005). Taken together, these more or less coordinated efforts of the state give narrative structure, internal coherence and emotional weight to the nation.

Nationalism, in this sense, is an act of production. But who then are its consumers? While nationalists throughout history have viewed the people as the ultimate repository of national values and the bearers of national traditions, the people have not always viewed themselves in the same way. Ordinary people are not simply uncritical consumers of the nation; they are simultaneously its creative producers through everyday acts of consumption (Billig, 1995; Edensor, 2002; Foster, 2002; Palmer, 1998). Yet while the state-sponsored production and propagation of the nation have been well documented, less attention has been focused on the precise ways in which these national products and projects are received and consumed by the people at whom they are aimed.

Consumption constitutes, reinforces and communicates social membership: it makes 'visible and stable the categories of culture' (Douglas and Isherwood, 1996[1976]: 38; see more generally 36-52). Various studies have explored how such diverse axes of social differentiation ranging from class (Bourdieu, 1984[1979]) and gender (Ang, 1985) to race (Lamont and Molnár, 2001) and national belonging (Foster, 2002; Edensor, 2002) are constructed and concretized through the routine consumption practices of everyday life. This is not the collective effervescence evinced through ritual performance, but rather the quotidian experience of sameness - a vague self-awareness of shared dispositions that materialize through consumption (see Edensor, 2002: Chapter 3). We shift our attention here to this consumption side of the equation.

\section{Consuming national products}

Some products are conceived, designed and disseminated as more or less national products. The flag is not just a symbol of the nation; it is also a thing that can be bought and sold, copied and distributed. It can be hung from flagpoles or windows, draped over shoulders or coffins, stitched into jackets 
or baseball caps and stuck on to car bumpers or envelopes. This is the commodification of the nation: national (and nationalist) literature, media, music, costumes and food provide people with nationally marked (or markable) products for their national consumption needs. In the postSoviet context, Melissa Caldwell (2002) has shown how ordinary people have reclaimed and rearticulated their Russianness through the consumption of what is seen (and therefore constituted) as Russian food. Their consumption preferences and practices become everyday sites for defending and defining the socialist values of Russian nationalism against the onslaught of global capitalism (Caldwell, 2002: 305-13). Consumers don't simply buy national commodities; they constitute national sensibilities, embody national pride, negotiate national meanings, thus making nationhood a salient feature of their everyday lives.

Consumption doesn't only occur only at the cash register. School curricula - the preferred purveyors of national (and sometimes nationalist) meanings, myths and memories - are also consumed and imbibed (and sometimes deflected and subverted) by pupils in classrooms around the world. Students are not merely passive receptacles of nationalist messages, nor are their teachers their unquestioning conduits (Aronowitz and Giroux, 1993). Rather, as Miller-Idriss (forthcoming) has demonstrated in the German case, both students and teachers are active participants in the creative interpretation and constitution of understandings of nationhood that may bear little resemblance to those packaged in official curricula.

Media that are national in scope, content and/or format can also contribute to the activation and reinforcement of national sensitivities. Readers of nationalist newspapers and viewers of cultural programming are not only aligning themselves with their putative nations but actively interpreting and expressing the meaning of those alignments. And nationally marked and decorated spaces and places - public squares, national landmarks and entire regions (Löfgren, 1989; Molnár, 2005) - can similarly be seen, appreciated and therefore consumed in ways that highlight and privilege national attachments. Joshua Hagen (2004) has shown how the medieval German town of Rothenburg was transformed and contrived as the epitome of Germanness in the 1930s. Local residents became actively engaged in the production - and consumption - of their own exalted values of Teutonic cleanliness, order and beauty (Hagen, 2004: 214-18).

The commodification of the nation supplies ordinary people with moreor-less nationally marked products whose consumption can engender and reinforce a national view of the world (Edensor, 2002: 108-9). Through shopping and tourism, school lessons and television viewing, ordinary people make a national world visible to themselves and, potentially, those around them. The consumption of these national artefacts defines, demonstrates, and affirms the consumer's national affinities. It marks the products - and the people who consume them - nationally. 


\section{Consuming products nationally}

The consumption of products with explicitly national contents and parameters can help make nationhood a meaningful feature of everyday life. But 'intrinsically' national products do not always engender explicitly national sensibilities. Literary figures that may be cherished as national treasures by their compatriots might simultaneously enjoy cosmopolitan reputations in international circles. Music that might be celebrated as evoking the national heritage of some nations might appeal to amazon.com shoppers as world music (Haynes, 2005). And food that might be a favourite national dish for some might simply be lunch for others. Indeed, while nationally minded consumers give expression to their national sensibilities through the consumption and display of their 'own national' artefacts, others consume the same artefacts, rechristened 'world culture', to demonstrate and perform their (ostensible) cosmopolitanism.

It is not the intrinsic properties of these products but rather the shifting modalities through which meaning is attached to them that distinguishes national consumption from other forms of consumption. The focus in the literature on consumption of cultural artefacts with seemingly national qualities overlooks the extent to which consumption is simultaneously itself an act of production. The consumption of 'non-national' products in nationally distinct ways can thus also engender national distinctions.

Indeed, even the most global products can be subject to local appropriation in different, sometimes national, ways. Daniel Miller (1998), for instance, has shown how the consumption of Coca-Cola ${ }^{\circledR}$, the symbol of globalization par excellence, is appropriated by African and Indian Trinidadians to construct and maintain local ethnic and racial distinctions. In Scandinavia, Anders Linde-Laursen (1993) has shown how washing up becomes an everyday site for ordinary Danes and Swedes to perform and produce national difference. And Daphne Berdahl (1999) has examined how east Germans have been incrementally purchasing Germanness (in its western variant) through their appropriation and emulation of postcommunist patterns of consumption.

Public spaces can also become endowed with national meaning not only through the intentions of their architects but also through the interpretations of their everyday users. Restaurants, bars and cafés become national hangouts through practice rather than design; squares, parks, buildings and neighbourhoods similarly get marked in ways that can make nationhood a salient feature of those who encounter them. In multiethnic Romania, certain establishments are seen and therefore marked as Hungarian, not by the signs hanging in front of them but rather through the everyday consumption practices of their Hungarian clientele (Brubaker et al., 2006: 296). And years after reunification in Germany, the internal design and organization of police stations in Berlin mark them unambiguously as 
eastern and western to the officers who inhabit them (Glaeser, 1999). The preferences and practices of spatial consumption mark and constitute the places of everyday life in nationally relevant ways.

The media, too, can be nationally consumed even when they're not national in scope, content or format. The consumption preferences of nationally delineated audiences for non-national media can engender and reinforce the experience of shared national belonging (Moores, 1997, 1993). Viewers tuned into the same broadcasts or readers flipping through the same papers acquire shared 'cultural competencies' (Moores, 1997: 230), the boundaries of which coincide with those of the viewing or reading public. 'Opening the pages of the newspaper', explains Moores (1993: 87), 'and, we might add, switching on the news bulletin at the same time every evening ...- are ritual practices which enable us to imagine ourselves as part of a social collectivity that shares in the same anonymous, simultaneous activity' (see also Anderson, 1991: 34-6). It makes people national, but not necessarily nationalist. In Transylvania, many Hungarians read the local Hungarian paper not for its nationalist commentary but rather for the death notices and television listings of the Hungarian community to which they see themselves (and therefore constitute themselves) as belonging (Brubaker et al., 2006: 293-4). Nationally demarcated media can organize the wholly nonnational content of their audience's cultural repertoires along national lines (Storey, 1999: 113-19). ${ }^{5}$

In these and other ways, it is not the inherent national qualities of the products consumed but the consumption of non-national products in nationally discernable ways that contribute to the emergence of nationally defined communities (of consumers). Shared national consciousness need not be premised on the practical mastery of the same national (or nationalist) canon; it can also congeal within parameters that are explicitly defined as national. Routine consumption practices thus become important modalities for the production of national sensibilities. They provide people with occasions for establishing, upholding and reproducing national difference in ways that follow not from elite designs but rather correspond to the contingencies of their daily lives.

\section{CONCLUSION, OR HOW TO STUDY EVERYDAY NATIONALISM}

The broad brush strokes favoured by macro-analytical approaches to the study of nationalism blur (and sometimes obscure) the finer grains of the nation that are embedded in the routine practices of everyday life. We cannot properly appreciate the variable meaning and salience of nationhood in everyday life by only studying its state-sponsored construction, 
modern industrial context or elite manipulation. This is not to suggest that everyday nationhood should be studied independently of these phenomena. But this is where our study begins; not where it ends. Nations are not just the product of structural forces; they are simultaneously the practical accomplishment of ordinary people engaging in mundane activities in their everyday lives.

We have attempted to shift attention to everyday life as a domain in its own right for the study of nationalism. This does not mean the nation pervades everyday life (cf. Billig, 1995); most of the time, it doesn't. Even in parts of the world characterized by intractable and polarizing nationalist politics, ordinary people are often indifferent to national(ist) claims made in their names (Brubaker et al., 2006; Fenton, 2007; Fox, 2004a). This popular indifference to the more stylized rhetoric peddled by politicians suggests that there is a disjuncture between nationalist politics on the one hand and the ways in which ordinary people understand and represent themselves and their predicaments in national terms on the other (Brubaker et al., 2006; Fox, 2004b; Herzfeld, 1997). Nationalism does not resonate evenly or resoundingly in everyday life.

The actual ways in which the nation does come to matter to ordinary people cannot therefore be inferred from its political robustness. Our aim here has been to specify the actual practices and processes through which nationhood is reproduced in everyday life by its ordinary practitioners. We take Hobsbawm's call to study nationalism 'from below' seriously by elaborating some of these ways in which people enact, constitute, legitimate and sometimes undermine the idiom of the nation in the diverse contexts of their everyday lives.

In a sense, ours is a plea to take social constructivism seriously. The nation and its derivatives are not simply discrete objects traded in elite discourse or constructed by the state; they are also everyday processes: ways of doing, seeing, talking and being that implicate, enact, ratify and uphold a national view of the world (Brubaker, 2004). But while all agree that nations are social constructs, few have operationalized empirically grounded methodological agendas to systematically uncover the ways in which ordinary people participate in this national construction. We therefore build on the approaches elaborated in the previous sections to develop and propose a methodological agenda that studies the everyday construction of the nation in its own right.

In what remains, we briefly consider a mixture of methods that can be fruitfully deployed to study and appreciate nationhood in everyday life. This methodological agenda is guided by two interrelated domains of enquiry. First, we ask what is the nation in everyday life? This is the nation's everyday meaning and contents. Then we turn to the question, when is the nation in everyday life? This is the nation's everyday salience and contexts. We consider appropriate methods for the study of each set of questions. 


\section{What is the nation?}

What, then, does the nation mean to ordinary people? We propose a methodology that looks not first to political speeches, newspaper articles or history textbooks for the nation's everyday meanings, but rather puts the questions to the audiences of the speeches, the readers of newspapers, and the pupils of history - and to those who don't listen to speeches, read papers or do their history lessons.

Survey research can be particularly useful in this regard. Questions about political and cultural attitudes, in-group and out-group stereotypes, and social distance scales shed light on the diversity of ways in which ordinary people understand themselves and the world around them in national terms. Surveys are effective instruments for gaining a general overview of the national sensibilities of relatively large segments of the population.

Surveys are less well suited, however, for capturing variation in the nuance and texture of everyday nationhood. For this, more qualitative modes of investigation are helpful, such as interviewing and focus groups. These methods (used in conjunction with survey methods) can provide a richer and more balanced picture of the scope, depth and content of the everyday meanings of the nation. Interviews and focus groups provide researchers with opportunities for exploring ordinary people's discursive representations of nationhood in terms chosen by the interviewee - not the interviewer. They also record the sorts of non-verbalized manifestations of everyday nationhood that are missed by survey methods. The nation is not only expressed discursively; it is also embodied in non-discursive forms the shrugs, grimaces, chuckles, winces and snorts that accompany (and sometimes replace) ordinary people's more articulate representations of nationhood. These embodied embellishments, missing from spreadsheets, can transform sincerity into cynicism, affiliation into disaffiliation and commitment into indifference. Ordinary people's talk (and body talk) reveals their capacity for articulating their understandings of the nation and aligning themselves with those understandings - in discursive and non-discursive ways meaningful to them.

\section{When is the nation?}

But just because people can talk nationally in these research settings doesn't mean that they do talk nationally in other contexts of their everyday lives. Ordinary people's practical mastery of the idiom of the nation, reproduced for social scientists in research settings of their own choosing, does not, in itself, explain the salience of such idioms in everyday life. Rather, it reflects a basic familiarity with the content and contours of nationhood that, when elicited, can be more-or-less competently deployed. But when is it elicited? Aside from those few odd times that students of nationalism come 
knocking at the doors of ordinary people with their grab bags of national questions, when - if, indeed, at all - do ordinary people engage the nation and its contents?

Other methods of data collection are needed as a corrective to contextualize national talk. While surveys and directed interview questioning can provide insight into what the nation means for ordinary people, they cannot, in themselves, explain when the nation matters to them. But the everyday contents of the nation cannot be properly appreciated detached from the everyday contexts in which they are invoked and evoked (Glaeser, 1999: 10, 21-2; see also Wimmer, 2004). Different contexts - from the microinteractional to the macro-structural - produce different types of talk and even substantively different views from the same people (Verkuyten et al., 1995: 262-4). Directed interview and survey questioning supply people with one set of contexts for talking nationally. But such talk must simultaneously be recognized as an artefact of the research settings in which it is solicited. Nationally framed questions typically elicit nationally framed answers. Strategies that pre-emptively tag the nation as a relevant frame of interpretation are less sensitive to the larger everyday contexts in which 'the nation' spontaneously happens - to the extent it does so at all. Left to their own devices, ordinary people may simply ignore or discard national categories in favour of other categories that are more suitable for their quotidian needs and wants.

We therefore propose a research agenda designed to leave people to their own devices. Rather than continually equipping interview subjects with our own national categories, we also adopt a 'wait-and-listen' approach to see how and when nationhood comes up in the discursive and interactional contexts of everyday life. Participant observation is best suited for this sort of investigation. More than any other method, participant observation is sensitive to context - not as it is supplied by the researcher but as it is constituted by ordinary people according to the contingencies of their everyday lives. Participant observation provides a window for viewing the nation in everyday life. This is the nation as it is marked in accents and codeswitching, displayed in dress and demeanour, cued by sights and sounds, and responded to in news broadcasts and history classrooms. And this is the nation as it is also deflected, ignored and subverted in these same and other contexts. These quotidian fluctuations in nationhood can easily be missed in interviews or distorted by surveys. Researchers interested in the salience of nationhood in everyday life therefore need to spend some time in everyday life. This requires a wait-and-listen approach because most of everyday life is devoid of national inflection. But such is the study of everyday nationalism: nationhood, it turns out, is not salient across time or space. The contexts in which it matters to ordinary people need to be specified.

Indirect questioning in interview and focus group settings can also prove 
useful for assessing the everyday salience of the nation. But rather than only asking questions about what the nation means to ordinary people, strategies need to be formulated for asking questions about when the nation matters to them. Nationhood can manifest itself not only as a topic of conversation, but also as an interpretative frame for making sense of other topics of conversation. Researchers should thus consider questions on topics that allow (but do not compel) those being interviewed to frame their responses in national terms. Such methods are useful for gauging when, how and in what (discursive) contexts the nation becomes a meaningful frame for ordering difference, explaining predicaments and interpreting social phenomena. Like participant observation, these strategies also entail a wait-and-listen approach, as much talk is simply non-national.

Ultimately, the contents and contexts of the nation are best studied in tandem. A singular focus on the nation's contents fails to take into account the everyday contexts in which those contents are embedded. Too much focus on the contexts of the nation, however, ignores the ways in which people's non-verbalized mastery of national idioms can invisibly undergird routine talk and interaction. We propose, therefore, a mixed-methods approach that is sensitive to the variable meaning and contextual salience of nationhood in everyday life (Brubaker et al., 2006: 380-5; Fox, 2004b: 24-9).

We have explored just some of the ways in which the empirical study of everyday nationalism might be undertaken. In the aggregate, the varied approaches elaborated in the preceding sections contribute to a burgeoning scholarship on the quotidian meanings, uses and salience of nationhood. Our goal here has been to harness these contributions under the banner of everyday nationhood and develop a research agenda for the systematic study of the phenomenon. This is the view of nationalism from below.

\section{Acknowledgements}

We thank John Hall for his critical feedback on an earlier version of this paper presented at the Annual Meeting of the American Sociological Association, Montreal, August 2006. We are also indebted to Rogers Brubaker, Steve Fenton, Gail Kligman, and Andy Thompson for their comments.

\section{Notes}

1 There is a substantial scholarship on everyday life growing out of French (see especially de Certeau, 1984) and German traditions (the Alltagsgeschichte school of historiography). More recently, renewed interest in the field has come from a variety of social scientific perspectives (witness Routledge's 'New Sociology' series with all 12 of its titles on 'everyday life'). While recognizing the intellectual traditions out of which this scholarship has grown, our own use of 'everyday life' is a bit more 'everyday'. That is, we define everyday life as a domain of enquiry. Though its boundaries are not easily marked or maintained, in the study 
of nationalism everyday life is to be understood as a realm for the routine (and sometimes not so routine) activities of ordinary people. In this sense, everyday life is to be distinguished from that field of activities coordinated and pursued by (national) elites.

2 Broadly speaking, our interest is in the relationship between politicized forms of collective belonging on the one hand and their everyday analogues on the other. Practically speaking, however, we limit our discussion to nations and nationalisms on the one hand and everyday nationhood on the other. While we will occasionally refer to ethnicity and its derivatives (particularly when such terminology is employed in the studies we reference), we do not treat such instances of ethnicity as analytically distinct from nationhood. This is not to say that nationhood and ethnicity are the same thing. Rather, it is to acknowledge that there is conceptual overlap in the ways in which ordinary people use such terms in their everyday lives. Our usage follows the practices and preferences of these ordinary people.

3 The question could also be posed as 'where is the nation?' Our aim here is to situate the nation not only temporally but also spatially in the routine contexts of everyday life.

4 Other non-linguistic cues also signal membership in the nation. Visual and embodied markers, such as style of dress, physical comportment, phenotype and behaviour can make ethnonational affiliation transparent (Edensor, 2002; see also Goffman, 1959). Many visual cues (particularly phenotypes) can function as conspicuous (and at times inescapable) markers of ethnonational belonging. Miller-Idriss's research in Germany (forthcoming) shows how the national affiliation of non-ethnic Germans is imputed by others based on phenotype and/or dress. Julia, a twenty-something Palestinian who came to Germany as a child, reported feeling like a foreigner as an adult. 'How can I explain it?', she asked. 'Actually, my habits are German, because I've been living here since I was nine. But people separate you off in a lot of ways: "Yeah, what are you doing here?", Mehmet, another twenty-something born in Germany to Turkish parents, explained that despite feeling German, he was not accepted as one of them: 'How can you feel like a German?', Germans say to him. 'How can I not feel like a German?', he responds: 'I was born here.' While there were situations in which their non-ethnic German backgrounds were less relevant, neither felt they were entirely escapable. Despite both being German citizens and seeing themselves in some way as culturally German, Julia and Mehmet were regarded as 'foreigners' by their German interlocutors.

5 'Membership in a people', Karl Deutsch (1966: 86-100) reminds us, 'essentially consists in a wide complementarity of social communication. It consists in the ability to communicate more effectively, and over a wider range of subjects, with members of one large group than with outsiders' (1966: 97). 'It matters precious little', adds Ernest Gellner (1983: 127), 'what has been fed into them [the community]: it is the media themselves, the pervasiveness and importance of abstract, centralized, standardized, one to many communication ... quite irrespective of what in particular is being put into the specific messages transmitted.' 


\section{References}

Anderson, Benedict (1991) Imagined Communities: Reflections on the Origin and Spread of Nationalism (2nd edition). London: Verso.

Ang, Ien (1985) Watching Dallas: Soap Opera and the Melodramatic Imagination. London: Methuen.

Aronowitz, Stanley and Henry A. Giroux (1993) Education Still under Siege: Critical Studies in Education and Culture (2nd edition). Westport, CT: Bergin \& Garvey.

Banton, Michael (1983) Racial and Ethnic Competition. Cambridge: Cambridge University Press.

Baumann, Gerd (1996) Contesting Culture: Discourses of Identity in Multi-Ethnic London. Cambridge: Cambridge University Press.

Berdahl, Daphne (1999) Where the World Ended: Re-Unification and Identity in the German Borderland. Berkeley, CA: University of California Press.

Berezin, Mabel (1997) Making the Fascist Self: The Political Culture of Interwar Italy. Ithaca, NY: Cornell University Press.

Billig, Michael (1995) Banal Nationalism. London: Sage.

Bourdieu, Pierre (1977) Outline of a Theory of Practice. Cambridge: Cambridge University Press.

Bourdieu, Pierre (1984[1979]) Distinction: A Social Critique of the Judgement of Taste. Cambridge, MA: Harvard University Press.

Bourdieu, Pierre (1991) 'Identity and Representation: Elements for a Critical Reflection on the Idea of Region', in Language and Symbolic Power, pp. 220-28. Cambridge: Polity Press.

Bourdieu, Pierre and Jean-Claude Passeron (1977) Reproduction in Education, Society, and Culture. London: Sage.

Brinton, Mary C. and Victor Nee, eds (1998) The New Institutionalism in Sociology. New York: Russell Sage Foundation.

Brubaker, Rogers (1996) 'Nationhood and the National Question in the Soviet Union and its Successor States: An Institutionalist Account', in Nationalism Reframed: Nationhood and the National Question in the New Europe, pp. 23-54. Cambridge: Cambridge University Press.

Brubaker, Rogers (2004) Ethnicity without Groups. Cambridge, MA: Harvard University Press.

Brubaker, Rogers, Margit Feischmidt, Jon Fox and Liana Grancea (2006) Nationalist Politics and Everyday Ethnicity in a Transylvanian Town. Princeton, NJ: Princeton University Press.

Caldwell, Melissa (2002) 'The Taste of Nationalism: Food Politics in Postsocialist Moscow', Ethnos 67(3): 295-319.

Calhoun, Craig (1997) Nationalism. Minneapolis, MN: University of Minnesota Press.

Cerulo, Karen A. (1995) Identity Designs: The Sights and Sounds of a Nation. New Brunswick: Rutgers University Press.

de Certeau, Michel (1984) The Practice of Everyday Life. Berkeley, CA: University of California Press.

Deutsch, Karl W. (1966) Nationalism and Social Communication: An Inquiry into the Foundations of Nationality (2nd edition). Cambridge, MA: The MIT Press.

Dijk, Teun A. van (1984) Prejudice in Discourse: An Analysis of Ethnic Prejudice in Cognition and Conversation. Amsterdam: John Benjamins Publishing Company. 
Douglas, Mary and Baron Isherwood (1996[1976]) The World of Goods: Towards an Anthropology of Consumption. London: Routledge.

Durkheim, Emile (1995[1912]) The Elementary Forms of Religious Life. New York: The Free Press.

Edensor, Tim (2002) National Identity, Popular Culture and Everyday Life. Oxford: Berg.

Edensor, Tim (2006) 'Reconsidering National Temporalities: Institutional Times, Everyday Routines, Serial Spaces and Synchronicities', European Journal of Social Theory 9(4): 525-45.

Elias, Norbert and Eric Dunning (1986) Quest for Excitement: Sport and Leisure in the Civilizing Process. Oxford: Basil Blackwell.

Eriksen, Thomas Hylland (1993) 'Formal and Informal Nationalism', Ethnic and Racial Studies 16(1): 1-25

Fenton, Steve (2007) 'The Under-statement of National Identity: What Young Adults Think about Being English and British', Nations and Nationalism 13(2): 641-60.

Foster, Robert J. (2002) Materializing the Nation: Commodities, Consumption, and Media in Papua New Guinea. Bloomington, IN: Indiana University Press.

Foucault, Michel (1995[1977]) Discipline and Punish: The Birth of the Prison. New York: Vintage Books.

Fox, Jon E. (2004a) 'Missing the Mark: Nationalist Politics and Student Apathy', East European Politics and Societies 18(3): 363-93.

Fox, Jon E. (2004b) 'Nationhood without Nationalism: Being National in Everyday Life', PhD dissertation, Department of Sociology, University of California, Los Angeles, CA.

Fox, Jon E. (2006) 'Consuming the Nation: Holidays, Sports, and the Production of Collective Belonging', Ethnic and Racial Studies 29(2): 217-36.

Fox, Jon E. (2007) 'From National Inclusion to Economic Exclusion: Ethnic Hungarian Labour Migration to Hungary', Nations and Nationalism 13(1): 1-20.

Gamson, William A. (1992) Talking Politics. Cambridge: Cambridge University Press.

Geertz, Clifford (1973) 'Ideology as a Cultural System', in The Interpretation of Cultures, pp. 193-229. New York: Basic Books.

Gellner, Ernest (1983) Nations and Nationalism. Ithaca, NY: Cornell University Press.

Giles, Howard (1979) 'Ethnicity Markers in Speech', in Klaus R. Scherer and Howard Giles (eds) Social Markers in Speech, pp. 251-89. Cambridge: Cambridge University Press.

Glaeser, Andreas (1999) Divided in Unity: Identity, Germany and the Berlin Police. Chicago: The University of Chicago Press.

Goffman, Erving (1959) The Presentation of Self in Everyday Life. New York: Doubleday.

Gumperz, John J., ed. (1982) Language and Social Identity. Cambridge: Cambridge University Press.

Hagen, Joshua (2004) 'The Most German of Towns: Creating an ideal Nazi Community in Rothenburg ob der Tauber', Annals of the Association of American Geographers 94(1): 207-27.

Hahn, Carole L. (1998) Becoming Political: Comparative Perspectives on Citizenship Education. Albany, NY: State University of New York Press. 
Haynes, Jo (2005) 'World Music and the Search for Difference', Ethnicities 5(3): 55-85. Heller, Monica (1999) Linguistic Minorities and Modernity: A Sociolinguistic Ethnography. London: Longman.

Herzfeld, Michael (1997) Cultural Intimacy: Social Poetics in the Nation-State. New York: Routledge.

Hobsbawm, Eric J. (1991) Nations and Nationalism since 1780: Programme, Myth, Reality. Cambridge: Cambridge University Press.

Jenkins, Richard (1997) Rethinking Ethnicity: Identity, Categorization and Power. London: Sage.

Jones, Katharine W. (2001) “'I've Called 'em Tom-ah-toes All My Life and I'm Not Going to Change!": Maintaining Linguistic Control over English Identity in the US', Social Forces 79(3): 1061-94.

Kligman, Gail (1983) 'Poetry and Politics in a Transylvanian Village', Anthropological Quarterly 56(2): 83-9.

Koopmans, Ruud, and Paul Statham (1999) 'Challenging the Liberal Nation-state? Postnationalism, Multiculturalism, and the Collective Claims Making of Migrants and Ethnic Minorities in Britain and Germany', American Journal of Sociology 105(3): 652-96.

Kolst $\varnothing$, Pål. (2006) 'National Symbols as Signs of Unity and Division', Ethnic and Racial Studies 29(4): 676-701.

Laitin, David D. (1998) Identity Formation in Migration: The Russian-Speaking Populations in the Near Abroad. Ithaca, NY: Cornell University Press.

Lamont, Michèle and Virág Molnár (2001) 'How Blacks use Consumption to Shape their Collective Identity', Journal of Consumer Culture 1(1): 31-45.

Linde-Laursen, Anders (1993) 'The Nationalization of Trivialities: How Cleaning becomes an Identity Marker in the Encounter of Swedes and Danes', Ethnos 58(3-4): 275-93.

Löfgren, Orvar (1989) 'The Nationalization of Culture', Ethnologia Europaea 19: $5-24$.

Miller, Daniel (1998) 'Coca-Cola: A Black Sweet Drink from Trinidad', in Daniel Miller (ed.) Material Cultures: Why Some Things Matter, pp. 169-87.Chicago: The University of Chicago Press.

Miller-Idriss, Cynthia (2006) 'Everyday understandings of citizenship in Germany', Citizenship Studies 10(5): 541-70.

Miller-Idriss, Cynthia (forthcoming) Blood and Culture: Race, Citizenship, and National Belonging in a Re-Imagined Germany. Durham, NC: Duke University Press.

Molnár, Virág (2005) 'Cultural Politics and Modernist Architecture: The Tulip Debate in Postwar Hungary', American Sociological Review 70(1): 111-35.

Moores, Shaun (1997) 'Broadcasting and its Audiences', in Hugh Mackay (ed.) Consumption and Everyday Life, pp. 213-57. London: Sage.

Moores, Shaun (1993) Interpreting Audiences: The Ethnography of Media Consumption. London: Sage.

Mosse, George L. (1975) The Nationalization of the Masses: Political Symbolism \& Mass Movements in Germany from the Napoleonic Wars through the Third Reich. New York: Howard Fertig.

Nagel, Joane (1996) American Indian Ethnic Renewal: Red Power and the Resurgence of Identity and Culture. New York: Oxford University Press. 
Olzak, Susan, and Joane Nagel, eds (1996) Competitive Ethnic Relations. Orlando, FL: Academic Press.

Palmer, Catherine (1998) 'From Theory to Practice: Experiencing the Nation in Everyday Life', Journal of Material Culture 3(2): 175-99.

Petrone, Karen (2000) Life Has Become More Joyous, Comrades: Celebrations in the Time of Stalin. Bloomington, IN: Indiana University Press.

Powell, Walter W. and Paul J. DiMaggio, eds (1991) The New Institutionalism in Organizational Analysis. Chicago: The University of Chicago Press.

Rippberger, Susan J. and Kathleen Staudt (2003) Pledging Allegiance: Learning Nationalism at the El Paso-Juárez Border. New York: RoutledgeFalmer.

Smith, Anthony (1986) The Ethnic Origins of Nations. Oxford: Blackwell.

Soysal, Yasemin Nuhoğlu and Hanna Schissler, eds (2005) The Nation, Europe and the World: Textbooks and Curricula in Transition. New York: Berghahn Books.

Spillman, Lyn (1997) Nation and Commemoration: Creating National Identities in the United States and Australia. Cambridge: Cambridge University Press.

Storey, John (1999) Cultural Consumption and Everyday Life. London: Arnold.

Suny, Ronald Grigor, and Michael D. Kennedy, eds (2001) Intellectuals and the Articulation of the Nation. Ann Arbor, MI: The University of Michigan Press.

Thompson, Andrew (2001) 'Nations, National Identities and Human Agency: Putting People back into Nations', The Sociological Review 49(1): 18-33.

Thompson, Andrew and Graham Day (1999) 'Situating Welshness: "Local" Experience and National Identity', in Ralph Fevre and Andrew Thompson (eds) Nation, Identity and Social Theory: Perspectives from Wales, pp. 27-47. Cardiff: University of Wales Press.

Tilly, Charles (1998) Durable Inequality. Berkeley, CA: University of California Press.

Turner, Victor (1967) The Forest of Symbols: Aspects of Ndembu Ritual. Ithaca, NY: Cornell University Press.

Turner, Victor (1969) The Ritual Process: Structure and Anti-Structure. Ithaca, NY: Cornell University Press.

Verdery, Katherine (1991) National Ideology under Socialism: Identity and Cultural Politics in Ceauşescu's Romania. Berkeley, CA: University of California Press.

Verkuyten, Maykel, Wiebe de Jong and C.N. Masson (1995) 'The Construction of Ethnic Categories: Discourses of Ethnicity in The Netherlands', Ethnic and Racial Studies 18(2): 251-76.

Weber, Eugen (1976) Peasants into Frenchmen: The Modernization of Rural France, 1870-1914. Stanford, CA: Stanford University Press.

Wetherell, Margaret and Jonathan Potter (1992) Mapping the Language of Racism: Discourse and the Legitimation of Exploitation. New York: Harvester.

Whitmeyer, Joseph M. (2002) 'Elites and Popular Nationalism', British Journal of Sociology 53(3): 321-41.

Wimmer, Andreas (2004) 'Does Ethnicity Matter? Everyday Group Formation in Three Swiss Immigrant Neighbourhoods', Ethnic and Racial Studies 27(1): $1-36$.

Wodak, Ruth, Rudolf de Cillia, Martin Reisigl, and Karin Liebhart (1999) The Discursive Construction of National Identity. Edinburgh: Edinburgh University Press. 
Woolard, Kathryn A. (1989) Double Talk: Bilingualism and the Politics of Ethnicity in Catalonia. Stanford, CA: Stanford University Press.

Zubrzycki, Geneviève (2006) The Crosses of Auschwitz: Nationalism and Religion in Post-Communist Poland. Chicago: Chicago University Press.

JON E. FOX is a Lecturer in Sociology in the Department of Sociology at the University of Bristol, UK. Address: Department of Sociology, University of Bristol, 12 Woodland Road, Bristol. BS8 1UQ, UK. [email: jon.fox@bristol.ac.uk]

CYNTHIA MILLER-IDRISS is Assistant Professor of International Education and Educational Sociology in the Steindhardt School of Culture, Education and Human Devleopment at New York University. Address: 246 Greene Street Suite 300, New York, NY 10003, USA. [email: cmi1@nyu.edu]

\section{The limits of everyday nationhood}

\section{ANTHONY SMITH}

London School of Economics, UK

Some brilliant early essays by John Stuart Mill, Lord Acton and Ernest Renan apart, the study of nationalism is barely a century old. But, starting with the Austro-Marxists Otto Bauer and Karl Renner in the 1900s, and the historical analyses of nationalist ideology by Carlton Hayes, Louis Snyder and Hans Kohn from the 1920s, there has been a burgeoning literature on every aspect of nations and nationalism. In the post-war period, social scientists like Karl Deutsch (1966) and Ernest Gellner (1964 and 1983) joined the historians in their quest to uncover the intertwined causes of nationalism's appeal and the proliferation of nation states in the wake of decolonization. The high point of this social science approach was reached in the late 1970s and the 1980s with the publications of Michael Hechter (1975), Tom Nairn (1977), John Armstrong (1982), John Breuilly (1993[1982]), Benedict Anderson (1981[1982]), Eric Hobsbawm and Terence Ranger (1983), Anthony Smith (1986) and John Hutchinson (1987). The works of each of these scholars contained a 'grand narrative' of nationalism: an overall account of why and how the world became divided into nations, and why nationalism became the dominant ideology of the modern 